\title{
Jessica Tanner, Speculative Capital: Zola's Repossession of Paris
}

\section{Maria Emanuela Raffi}

\section{(2) OpenEdition}

1 Journals

\section{Edizione digitale}

URL: http://journals.openedition.org/studifrancesi/4442

DOI: $10.4000 /$ studifrancesi.4442

ISSN: 2421-5856

\section{Editore}

Rosenberg \& Sellier

\section{Edizione cartacea}

Data di pubblicazione: 1 settembre 2016

Paginazione: 357

ISSN: 0039-2944

\section{Notizia bibliografica digitale}

Maria Emanuela Raffi, « Jessica Tanner, Speculative Capital: Zola's Repossession of Paris », Studi

Francesi [Online], 179 (LX | II) | 2016, online dal 01 septembre 2016, consultato il 18 septembre 2020.

URL : http://journals.openedition.org/studifrancesi/4442; DOI : https://doi.org/10.4000/studifrancesi. 4442

Questo documento è stato generato automaticamente il 18 settembre 2020.

\section{(c) (1)}

Studi Francesi è distribuita con Licenza Creative Commons Attribuzione - Non commerciale - Non opere derivate 4.0 Internazionale. 


\title{
Jessica Tanner, Speculative Capital: Zola's Repossession of Paris
}

\author{
Maria Emanuela Raffi
}

\section{NOTIZIA}

JESSICA TANNER, Speculative Capital: Zola's Repossession of Paris, in «L'Esprit Créateur» 55, n. 3, 2015, pp. 114-126.

1 Il sogno del giovane Zola di catturare nei suoi testi la Parigi in piena trasformazione del Secondo Impero e di farne addirittura la protagonista di uno dei suoi romanzi, sulle orme delle descrizioni di Balzac e Flaubert, è l'argomento dell'articolo di Jessica Tanner, che sostiene la somiglianza fra lo scrittore e il protagonista de La Curée, entrambi «speculators» nei confronti dello smembramento di Parigi operato da Napoleone III e da Haussmann. La Tanner propone in effetti di accostare le strategie di dominio dello spazio - che a sua volta risulta vincitore sul tempo - attuate da Haussmann (e da Sicard) in una Parigi trasformata in una sorta di serra sperimentale, con le strategie dello scrittore naturalista, descritte da Zola come esercizio di un dominio assoluto sullo spazio e sul tempo. L'immagine della hothouse appare al centro di questa riflessione: la serra "reale" della Curée zoliana, in cui Saccard si occupa, interpretando il gusto del tempo, del Parc Monceau come luogo di acclimatazione delle piante esotiche e la mappa di Parigi tracciata come una forzata acclimatazione di elementi estranei da Haussmann si incrociano nell'estetica zoliana con la visione immaginaria della città, concepita come luogo sperimentale, prodotto di una concezione sperimentale della scrittura. 